О.С. Мавренков ${ }^{1}$, П.М. Стешенко ${ }^{1}$, А.О. Мавренкова ${ }^{2}$

${ }^{1}$ Державний науково-дослідний інститут авіації, Київ

${ }^{2}$ Національний авіаційний університет, Київ

\title{
ДО ПИТАННЯ БАГАТОКРИТЕРІЙНОГО ПОРІВНЯЛЬНОГО ОЦНЮЮАННЯ БЕЗПІЛОТНИХ АВІАЦІЙНИХ КОМПЛЕКСІВ
}

Представлено результати досліджень з удосконалення методичного апарату порівняльного оцінювання безпілотних авіаційних комплексів у напрямах більш повного врахування складових фінансових витрат і ризикоутворюючих факторів, щзо супроводжують прочеси реалізації проєктів постачання (розроблення) таких комплексів. Як критерій витрат пропонується використовувати вартість життєвого циклу безпілотного авіаційного комплексу. Як критерій успішності реалізації проєктів постачання (розроблення) безпілотних авіаційних комплексів у системі можливих ризиків пропонується використовувати відносний показник долі суми індексів неприпустимих ризиків серед всіх ідентифікованих ризиків, щзо супроводжують проєкт. Визначено напрями подальших досліджень в частині апробації запропонованого методичного апарату.

Ключові слова: безпілотний літальний апарат, складна технічна система, коефіиієнт технічного рівня, вартість життєвого ичиклу, ризики, багатокритерійний вибір.

\section{Вступ}

Постановка проблеми. Різноманіття класів і типів безпілотних авіаційних комплексів (БпАК), які на сьогодні пропонуються на світових ринках авіаційної техніки, обумовлюють актуальність задачі їх порівняльної оцінки при виборі кращих (потрібних, ефективних) зразків. При цьому така задача обумовлюється складністю прийняття оптимального рішення на фоні багатопараметричності та складності БПАК як технічних систем. Ефективне вирішення зазначеної задачі можливо на основі розвиненого науковометодичного апарату в системі прийняття відповідних рішень.

\section{Аналіз останніх досліджень і публікацій.}

Як показує аналіз відомих публікацій за темою дослідження, задача вибору зразків озброєння та військової техніки (ОВТ), як складних технічних систем (СТC), в методологічному плані вирішується, в переважній більшості, шляхом комплексного застосування критеріїв “ефект (якість) - вартість" [1, с. 10, 11; 2, с. 144; 3, с.14; 4, с. 173...174].

Як показник ефективності застосування зразків ОВТ у переважній більшості відомих методик використовується ймовірність виконання завдання у відповідності до цільового призначення зразків [5, c. 32...35]. При цьому розрахунок зазначеного показника відбувається, як правило, шляхом математичного (імітаційного) моделювання процесу застосування (використання) зразка ОВТ [4, с. 204;
5 , с. 13,$14 ; 6$, с. $109 ; 7$, с. $63 ; 8$, с. $25 \ldots 28]$. Такий методичний підхід до оцінювання ефективності застосування зразка ОВТ потребує розроблення складних повномасштабних математичних моделей (MM) 3 підтвердженням їх адекватності та достовірності.

Принциповий вигляд зазначених ММ може бути відображено залежністю:

$$
M_{N}=F\left(N_{i}, K_{i}, \Lambda_{i}, U, Z, \Delta_{k}, \Pi_{l}\right),
$$

де $F$ - символ моделі; $N_{i}$ - кількість $i$-х зразків БпАК, що беруть участь у операції; $K_{i}$ - показник технічного рівня $i$-го БпАК; $\Lambda_{i}$ - рівень підготовки операторів $i$-го БПАК; $U$ - показник ефективності функціонування підсистеми управління; $\boldsymbol{Z}$ - показник ефективності функціонування підсистеми забезпечення; $\Delta_{k}-$ характеристики $k$-го об'єкту дії БпАК (віддалення від місця базування (злету) БпАК, розміри об'єкта, його контрасність тощо); $\Pi_{l}-l$-ті умови застосування зразка (час доби, метеоумови, форми та способи застосування і таке інше).

Очевидно, що розроблення таких ММ потребує залучення значної кількості висококваліфікованих спеціалістів та великих трудовитрат, що пов'язано 3 необхідністю формалізації оточуючого середовища й прийомів (способів) застосування зразків ОВТ. При цьому бажання досягнути потрібної адекватності математичного моделювання реальному процесу застосування ОВТ супроводжується збільшенням факторів, які повинні враховуватись, що зазвичай 
веде до невиправданого ускладнення МM i накопиченню ними критичних помилок.

Мета статті - представити результати дослідження авторів з удосконалення методичного апарату порівняльного оцінювання БпАК на основі методів багатокритерійної оптимізації та обгрунтувати напрями подальших досліджень.

\section{Виклад основного матеріалу}

Як показує практика, задача порівняльного аналізу альтернативних БПАК може бути вирішена поза межами повномасштабного математичного (імітаційного) моделювання. Це твердження витікає 3 тієї умови, що порівняння альтернативних зразків повинно здійснюватися для однакових способів їх застосування та у однакових умовах функціонування. А значить необхідність формалізації оточуючого середовища та прийомів (способів) застосування БпАК втрачає сенс. Як було показано вище, за цих умов ефективність застосування БпАК буде однозначно визначатися тільки його якістю як СТС.

Інтегральною характеристикою якості СТС $є$ іï технічний рівень (ТР), що являє собою певну згортку основних показників технічної досконалості (технічних характеристик) СТС. Як показник технічного рівня СТС використовується коефіцієнт технічного рівня (КТР), що визначає ступінь (рівень) якості СТС по відношенню до базового зразка-аналога [9, с. 9].

Відомі методики оцінювання КТР СТС засновуються на методологічному апараті кваліметрії - науки, що займається проблематикою кількісних оцінок якості об'єктів (виробів, процесів) $[10$, с. $267 ; 11$, с. 178,179$]$. Розрахунок КТР СТC засновується на математичному апараті оцінювання технічного рівня (якості) СТС за співвідношенням визначальних показників технічної досконалості (технічних характеристик) оцінюваної й базової (еталонної) СТC 3 урахуванням відносної важливості цих показників. Під визначальними розуміють показники (характеристики), що мають найбільший (вирішальний) вплив на ефективність застосування (використання) СТС за їі цільовим призначенням.

Процедура оцінювання КТР БПАК повинна починатися 3 аналізу його цільового призначення та сукупності завдань, що будуть ним вирішуватися. При цьому БПАК подається у вигляді СТС, яка утворюється із функціонально зв'язаної сукупності підсистем. Кожна з таких функціональних підсистем характеризується сукупністю множин іiі власних параметрів (технічних характеристик), які узагальнюють в собі весь спектр можливостей БпАК виконувати завдання за цільовим призначенням.
Методика розрахунку КТР БПАК засновується на принципі функціональної декомпозиції та тонкоструктурного порівняльного аналізу визначальних показників (характеристик) такого БПАК. Проведення цього аналізу передбачає побудову багаторівневої ієрархічної структури показників технічної досконалості (технічних характеристик) БпАК та виділення 3 них визначальних.

Формальний вигляд КТР БпАК може бути представлено у вигляді:

$$
K=\sum_{k=1}^{M} \sum_{k_{i}=1}^{N_{k}} \delta_{k} \gamma_{k_{i}} \frac{\bar{\chi}_{k_{i}}}{\bar{\chi}_{k_{i}}^{\text {бaз }}}
$$

де $\delta_{k}$ - коефіцієнт вагомості $k$-ої функціональної підсистеми БпАК, який оцінюється рівністю $\sum_{k=1}^{M} \delta_{k}=1 ; \gamma_{k i}-$ коефіцієнт вагомості $\boldsymbol{i}$-го показника технічної досконалості (технічних характеристик) $k$-ої функціональної підсистеми БпАК, який оцінюється рівністю $\sum_{k_{i}=1}^{N_{k}} \gamma_{k_{i}=1} ; M-$ кількість функціональних підсистем оцінюваного БпАК; $N_{k}$-кількість визначальних показників технічної досконалості (технічних характеристик) $k$-ої функціональної підсистеми оцінюваного БпАК; $\bar{\chi}_{k_{i}}, \bar{\chi}_{k_{i}}^{\text {баз }}$ приведені значення $i$-го показника технічної досконалості (технічної характеристики) $k$-ої функціональної підсистеми оцінюваного та базового БпАК відповідають рівностям:

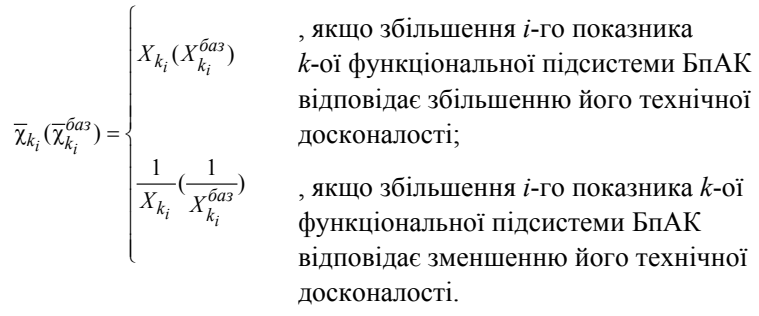

$X_{k_{i}}, X_{k_{i}}^{\text {баз }}-$ натуральні значення $i$-го показника технічної досконалості (технічної характеристики) $k$-ої функціональної підсистеми оцінюваного та базового БпАК відповідно.

Тобто, для прийняття рішення 3 вибору кращого (щодо поняття технічної досконалості) зразка БпАК з числа альтернативних, достатньо визначити та порівняти між собою їх технічні рівні (рівні якості) по відношенню до певного базового (еталонного) зразка.

Другим критерієм у системі порівняльного оцінювання альтернативних БпАК виступають фінансові витрати (вартість).

Відомі методики техніко-економічного аналізу БпАК, як правило, використовують такі показники 
фінансових витрат: вартість розроблення БпАК; ринкова вартість БПАК; вартість контракту на поставку певної кількості (партії) БПАК; вартість однієї години експлуатації БпАК. Крім того, існують підходи, в основу яких покладено оцінювання зміни контрактної питомої ціни зразка, як відношення ціни серійного зразка БПАК до маси його пустого [12, с. 103].

Кожний окремий 3 перелічених вартісних показників не дозволяє коректно використовувати його у системі прийняття рішень щодо вибору БпАК, оскільки не враховує у повній мірі фінансові витрати, що пов'язані як власне 3 процедурою його закупівлі, так і подальшою його експлуатацією (утриманням).

Таким чином, проведений аналіз показує, що представлений методичний підхід порівняльного аналізу БпАК в системі критеріїв “ефективність (якість) - вартість" не в повній мірі враховує необхідні (визначальні) аспекти процесу оцінки БпАК при їх виборі. По-перше, вартісні показники БпАК, які використовуються, носять обмежений інформативний характер i не враховують у комплексі експлуатаційні та інші витрати впродовж життєвого циклу БпАК. А, як відомо, наприклад, тільки експлуатаційні витрати можуть складати до $70 \%$ витрат за період життєвого циклу БпАК [11, с. 189]. По-друге, не враховуються можливі ризики, які супроводжують процеси постачання (розроблення) БПАК, що може призвести до збитків i / або зриву реалізації запланованих проєктів.

Авторами пропонується удосконалення існуючого методичного апарату оцінки БпАК шляхом: 1) використання як критерію вартості вартості життєвого циклу БПАК; 2) введення додаткового критерію - інтегрального ризику реалізації проєкту постачання (розроблення, закупівлі) БпАК.

Аналіз процесів життєвого циклу проєктів постачання БпАК показує, що основними складовими вартості їх реалізації в загальному випадку є: кількість БпАК, що постачається; вартість власне БпАК; зв'язані витрати (обладнання та послуги); вартість години експлуатації БпАК; середньорічний наробіток (наліт) БпЛА у годинах; призначений строк/ресурс експлуатації БпАК у роках / годинах; вартість розроблення БпАК або вартість придбання ліцензії на виробництво БпАК; витрати на підготовку виробництва.

В загальному випадку показник $C$ вартості життєвого циклу БпАК може бути розраховано за формулою:

$$
C=N\left(C_{1} \cdot K_{3 B}+C_{\Gamma E} \cdot \tau \cdot T\right)+\left[C_{P}+C_{\Pi B}+C_{Л}\right]+C_{У T},
$$

де $N$ - кількість БпАК (БПЛА), що постачаються; $C_{1}$ - вартість одного БпАК; $K_{3 B}-$ коефіцієнт зв'язаних витрат; $\quad C_{\Gamma E}-$ вартість години експлуатації; $\tau$ - середньорічний наробіток (наліт) БПАК у годинах; $T$ - призначений строк експлуатації БпАК; $C_{P}$ - вартість розроблення БПЛА; $C_{\Pi B}-$ витрати на підготовку виробництва БпЛА; $C_{Л}-$ вартість ліцензії на виробництво БпЛА; $C_{У T}-$ вартість утилізації БпЛА.

При використанні формули (3) для оцінювання вартості реалізації проєктів закупівлі ЛА за імпортом такі їі складові, як $C_{P}, C_{\Pi B}, C_{Л}$ не враховуються. При використанні формули (3) для оцінювання вартості реалізації проєктів ліцензійного виробництва ЛА така іiі складова, як $C_{P}$ не враховується. При використанні формули (3) для оцінювання вартості реалізації проєктів розроблення та виробництва ЛА така ії складова, як $C_{Л}$ не враховується.

Спираючись на статистичні дані щодо вартісних характеристик укладених і реалізованих контрактів на закупівлю ЛА військового призначення, середнє значення коефіцієнта зв'язаних витрат може прийматися на рівні 1,5.

У вартість $C_{\Gamma E}$ години експлуатації БпАК включаються основні статті видатків на: паливномастильні матеріали, спеціальні рідини та гази; реновацію; капітальний ремонт; технічний супровід експлуатації; продовження строку служби / ресурсу; виконання регламентних робіт; утримування обслуговуючого персоналу; поточний ремонт; виконання робіт з модернізації; виконання доробок за бюлетенями; поповнення комплектів запасних частин і приладдя; накладні витрати. При цьому, сума всіх витрат за вказаними вище статями приводиться до однієї години польоту шляхом ділення на призначений ресурс БпАК.

Оцінювання інтегрального ризику $R$ проєкту засновується на методичному апараті теорії ризиків i полягає у вимірі фактичного рівня небезпеки кожного окремого ризику та у визначенні ступеня його впливу на проєкт. Таке оцінювання передбачає визначення параметрів кожного ризику (ймовірності настання та величини можливих збитків / втрат) i розрахунок рівня (індексу) $I_{r}$ ризику за формулою $[13$, с. $40 ; 14$, c. 65$]$ :

$$
I_{r}=U_{r} p_{r},
$$

де $U_{r}-$ величина збитку від настання $r$-го ризику; $p_{r}$ - ймовірність настання $r$-го ризику.

Індекс ризику є показником, що дає можливість судити про рівень загрози ризику. Процедуру його розрахунку доцільно виконувати за допомогою матриці “ймовірність - збиток” з розмірністю $5 \times 5$, яка будується на основі бальних експертних оцінок величини збитку від настання ризику (мінімальний, 
низький, середній, високий, максимальний) та імовірності його настання (слабоімовірний, малоімовірний, ймовірний, досить ймовірний, майже можливий) та, у відповідності до якої визначається рівень загрози ризику для проєкту [14, с. $66 . .69]$.

Для оцінювання інтегрального ризику проєкту відбирається група неприпустимих ризиків, настання яких $€$ критичним для успішного виконання проєкту та може призвести до його невиконання (зриву, провалу) в цілому.

Група неприпустимих ризиків формується на основі розрахунку індексу $I_{r}$ кожного $r$-го ризику, що пов'язує величину збитку з ймовірністю настання негативної події, що призводить до цього збитку, який визначається за формулою (4). Величина індексу $k$-го неприпустимого ризику становить від 12 до 25 одиниць $\left(12 \leq I_{q} \leq 25\right)$.

Інтегральний ризик $R$ реалізації проєкту пропонується представляти, як відношення суми індексів неприпустимих ризиків до суми індексів усіх ідентифікованих ризиків реалізації проєкту, за формулою:

$$
R=\frac{\sum_{q=1}^{Q} I_{q}}{\sum_{r=1}^{R} I_{r}},
$$

де $R, Q$ - кількості ідентифікованих ризиків та неприпустимих ризиків з числа ідентифікованих, відповідно; $I_{r}, I_{q}$ - індекси $r$-го ідентифікованого та $k$-го неприпустимого ризиків, відповідно.
Представлена виразом (5) величина $R$ за своїм фізичним змістом розглядається як очікувана ступінь ризикованості виконання проєкту в цілому. Значення величини $R$ знаходяться в межах від 0 до 1 , де значенню “ 1 ” відповідає очікуване невиконання (зрив, провал) проєкту, а значенню “0” - очікуване успішне виконання проєкту.

При цьому згідно рекомендацій теорії ризиків проєкт вважається доцільним до реалізації (відкриття) при очікуваній ризикованості його виконання не більше 0,2 .

\section{Висновки}

Таким чином, за представленими результатами досліджень отримано удосконалений методичний апарат порівняльного оцінювання БпАК, який, як очікується, забезпечить ефективну підтримку прийняття рішень за рахунок більш повного врахування складових фінансових витрат i ризикоутворюючих факторів, що супроводжують процеси реалізації проєктів постачання БпАК.

Подальші дослідження авторів буде зосереджено на ідентифікації можливих ризиків за окремими проєктами постачання (розроблення, закупівлі) БпАК і складанні розгорнутих їх переліків, аналізі їх параметрів (ймовірності настання ризиків та збитку від їх настання) i розрахунку відповідних індексів.

Результати апробації запропонованого методичного апарату буде представлено у подальших статтях авторів при порівняльному оцінюванні БпЛА I класу (мікро (тактичні), міні (тактичні поля бою) різних виробників.

\section{Список літератури}

1. Чобиток В.А. Оценка боевой эффективности и технического совершенства вооружения и военной техники. К.: КВВТИУ. 1984. -57 с.

2. Демидов Б.А. Теория и методы военно-научных исследований вооружения и военной техники. Харьков: ВИРТА ПВО. $1990 .-560$ c.

3. Семенов С.С., Харчев В.Н., Иоффин А.И. Оценка технического уровня образцов вооружения и военной техники. М.: Радио и связь, 2004. -552 с.

4. Системная методология планирования развития, предпроектных исследований и внешнего проектирования вооружения и военной техники: Монография / Демидов Б.А., Луханин М.И., Величко А.Ф., Науменко М.В.; под ред. Демидова Б.А. К.: ИД “Стилос”. 2011. - 464 с.

5. Боевые авиационные комплексы и их эффективность / И.В. Арбузов, О.В. Волочаев, И.И. Вольнов, А.В. Гостев, Л.В. Мышкин, Р.Н. Хабиров, В.Л. Шеховцов. Под ред. О.В. Болховитинов. М.: Изд. ВВИА им. проф. Н.Е. Жуковского. 2008. $-224 \mathrm{c}$.

6. В.М. Буренок, В.М. Ляпунов, В.И. Мудров Теория и практика планирования и управления развитием вооружения. М.: Изд-во “Граница". 2005. - 237 с.

7. Б.А. Демидов, О.А. Хмелевская Методический подход к формированию облика Перспективных боевых авиационных комплексов. Наука і техніка Повітряних Сил Збройних Сил України, 2010. - № 2(4). - С. 58-64.

8. Стешенко П.М. Математична модель для оцінювання ефективності бойового застосування розвідувальних безпілотних авіаційних комплексів. Озброєння та військова техніка. К.: ЦНДІ ОВТ ЗСУ. 2016. - Вип. № 2(10). - С. 25-28.

9. ДСТУ 2925-94. Якість продукції. Оцінювання якості. Терміни та визначення. [Чинний від 1996-01-01]. Вид. офіц. К.: Держстандарт України. 2010. - 34 с.

10. Беспилотные летательные аппараты: Методики приближенных расчетов основных параметров и характеристик/ Ильюшко В.М., Митрахович М.М. и др. Под ред. Силкова В.И. - К.: ЦНИИ ВВТ ВСУ. 2009. - 302с. 
11. Малогабаритные беспилотные авиационные комплексы (Mini UVS) / Башинский В.Г., Бзот В.Б. и др. Под ред. Леонтьева А.Б. / Монография - Запорожье: АО “Мотор Сич”. 2014. - 261 с.

12. Леженін С.І., Стешенко П.М. Методичні особливості оцінювання фінансових витрат у системі вибору альтернативних зразків безпілотних авіаційних комплексів військового призначення. Зб. наук. праць. - К.: ДНДІА,. 2016. - Вип. № 12(19). - С. 102-108.

13. Я.Д. Вишняков, Н.Н. Радаев. Общая теория рисков. М.: Издательский центр “Академия”. 2008. - 368 с.

14. ДСТУ IEC/ISO 31010: 2013. Керування ризиком. Методи загального оцінювання ризику. (IEC/ISO 31010:2009, IDT) [Чинний від 2014-07-01]. Вид. офіц. К.: Мінекономрозвитку України. 2015. - 80 с.

\section{Відомості про авторів:}

\section{Мавренков Олексій Єфремович}

доктор технічних наук старший науковий співробітник начальник науково-дослідної лабораторії Державного науково-дослідного інституту авіації, Київ, Україна

https://orcid.org/0000-0002-6578-4833

\section{Стешенко Петро Миколайович}

кандидат технічних наук

провідний науковий співробітник

Державного науково-дослідного інституту авіації, Київ, Україна

https://orcid.org/0000-0003-1432-6864

\section{Мавренкова Анастасія Олексївна}

Студентка

Національного авіаційного університету, Київ, Україна

https://orcid.org/0000-0002-3437-8234

\section{Information about the authors:}

\author{
Oleksii Mavrenkov \\ Doctor of Technical Sciences \\ Senior Researcher \\ Head of Research Laboratory \\ of State Research Institute of Aviation, \\ Kyiv, Ukraine \\ https://orcid.org/0000-0002-6578-4833
}

\section{Petro Steshenko}

Candidate of Technical Sciences

Leading researcher

of State Research Institute of Aviation,

Kyiv, Ukraine

https://orcid.org/0000-0003-1432-6864

\section{Anastasiia Mavrenkova}

Student

of National aviation university,

Kyiv, Ukraine

https://orcid.org/0000-0002-3437-8234

\title{
ON THE MATTER OF MULTICRITERIAL COMPARATIVE EVALUATION OF UNMANNED AVIATION COMPLEXES
}

\author{
O. Mavrenkov, P. Steshenko, A. Mavrenkova
}

The article presents the results of research to improve the methodological apparatus of comparative assessment of unmanned aerial vehicles. Today, the problem of choosing samples of armaments and military equipment (weapons) in methodological terms is solved in the vast majority by the integrated application of the criteria "effect (quality) - cost". In this case, as an indicator of the effectiveness of the use of samples of weapons used the probability of the task in accordance with their intended purpose, which is calculated using complex fullscale mathematical models (MM). In this case, the desire to achieve the desired adequacy of mathematical modeling of the real process of application of weapons is accompanied by an increase in the factors taken into account, which usually leads to unjustified complications of MM and their accumulation of critical errors. The authors propose to evaluate the effectiveness of UAV in terms of calculating the quality (technical level) of UAV as a complex technical system that does not require the development of complex simulation models with satisfactory accuracy of estimates. The authors improved the methodological apparatus of comparative assessment of UAV in the areas of more complete consideration of the components of financial costs and risk factors that accompany the processes of implementation of supply projects (development) of such complexes. It is proposed to use the cost of the life cycle of an unmanned aerial vehicle as a cost criterion. As a criterion for the success of the implementation of projects for the supply (development) of unmanned aerial vehicles in the system of possible risks, it is proposed to use the relative share of the sum of indices of unacceptable risks among all identified risks accompanying the project. The mathematical apparatus of calculation of selection indicators is given. The directions of further researches in the part of approbation of the offered methodical device are defined.

Keywords: unmanned aerial vehicle, complex technical system, technical level factor, life cycle cost, risks, multi-criteria choice. 